\title{
Antiguos actores de un nuevo régimen: indígenas y afrodescendientes en el Paraguay de la Independencia
}

Ignacio Telesca y Guillermo Wilde

\section{CpenEdition}

\section{Journals}

Edición electrónica

URL: https://journals.openedition.org/jsa/11920

DOI: 10.4000/jsa. 11920

ISSN: $1957-7842$

Editor

Société des américanistes

Edición impresa

Fecha de publicación: 20 diciembre 2011

Paginación: 175-200

ISSN: 0037-9174

\section{Referencia electrónica}

Ignacio Telesca y Guillermo Wilde, «Antiguos actores de un nuevo régimen: indígenas y afrodescendientes en el Paraguay de la Independencia», Journal de la Société des américanistes [En línea], 97-2 | 2011, Publicado el 10 diciembre 2014, consultado el 02 septiembre 2022. URL: http:// journals.openedition.org/jsa/11920 ; DOl: https://doi.org/10.4000/jsa.11920 


\title{
ANTIGUOS ACTORES DE UN NUEVO RÉGIMEN: INDÍGENAS Y AFRODESCENDIENTES EN EL PARAGUAY DE LA INDEPENDENCIA
}

\author{
Ignacio TELESCA y Guillermo WILDE *
}

\begin{abstract}
Este trabajo explora las características del proceso de independencia en la región del Paraguay, centrándose en la dinámica de las poblaciones indígenas y afrodescendientes. La primera parte analiza las respuestas al discurso de la Junta de gobierno de Buenos Aires en los pueblos locales. Sugerimos que dicho discurso, aunque a simple vista se orientaba a definir un "nuevo actor " político, expresaba en realidad un importante grado de continuidad con los lineamientos del Estado colonial en su etapa tardía. En ese contexto, los pueblos sujetos a la jurisdicción asuncena siguieron un camino político diferente al del área de influencia bonaerense, en buena medida impulsados por la situación poblacional y territorial que entonces imperaba en ellos. La segunda parte brinda detalles sobre las características de esa situación y su desarrollo desde las décadas anteriores, correspondientes al final del período colonial. Según suponemos, en esa dinámica previa se encuentran algunas de las claves para comprender las respuestas de la población indígena y afrodescendiente a los procesos de independencia en el Paraguay e, irónicamente, su rápido proceso de desaparición de los registros oficiales. [Palabras claves: frontera, mestizaje, indígenas, negros, Paraguay, Independencia.]
\end{abstract}

Acteurs anciens dans un régime nouveau: Indiens et descendants de Noirs dans le Paraguay de l'Indépendance. Ce travail est consacré à quelques-unes des caractéristiques $\mathrm{du}$ processus d'Indépendance dans la région du Paraguay, spécifiquement ce qu'il advint des populations indigènes et d'origine noire. Dans un premier temps, on examinera les réactions dans les villages au discours de la junte de Buenos Aires. On soutient ici que ce discours, quoique dirigé, à première vue, à definir un nouvel «acteur» politique, se situait en réalité dans la stricte continuité de ce que l'État colonial avait ébauché dans ses dernières années d'existence. Dans ce contexte, les villages dépendant de la juridiction d'Asuncion s'engagèrent sur une voie politique

* Consejo Nacional de Investigaciones Científicas y Técnicas (Argentina), Instituto de Investigaciones en Humanidades y Ciencias Sociales/UNLP-CONICET, Calle 48 e/ 6 y $7 \mathrm{~s} / \mathrm{n}^{\circ}, 8^{\circ}$ piso, La Plata, Argentina [itelesca@hotmail.com]; Instituto de Altos Estudios Sociales (UNSAM)/Consejo Nacional de Investigaciones Científicas y Técnicas (Argentina), Paraná 145, piso 5, CP C1017AAC Buenos Aires, Argentina [guillermowilde@gmail.com].

Journal de la Société des Américanistes, 2011, 97-2, pp. 175-200. C Société des Américanistes. 
distincte de ceux de l'aire d'influence de Buenos Aires, notamment sous l'influence des conditions démographiques et territoriales qui prévalaient chez eux. Dans un deuxième temps, on expose plusieurs caractéristiques de la situation et de son évolution en partant de la fin de l'époque coloniale. Selon nous, on peut trouver dans la dynamique pré-Indépendance, plusieurs clés des réponses des Indiens et des descendants de Noirs au processus d'indépendance et du pourquoi de leur disparition rapide des registres officiels. [Mots-clés: frontière, métissage, Indigènes, Noirs, Paraguay, Indépendance.]

Ancient actors for a new regime: Indigenous people and Afrodescendants in Paraguay during the Independence. This paper explores the caracteristics of the process of independence in the region of Paraguay focusing on the social dynamics of the Indigenous and African descent populations. The first part analyzes responses of the villages to the discourse of the Buenos Aires Junta Government. We suggest that said discourse, even though at a first glance seems to be oriented to define a « new political actor », actually expressed an important level of continuity with the directions of the Colonial State in its late phase. In this context, the villages subject to the Asunción jurisdiction took a political path different to those under the influence of Buenos Aires, conditioned by the demographic and territorial situation that prevailed in the region. The second part provides details about the caracteristics of this situation and its evolution since the previous decades, that correspond to the end of the colonial period. It is our contention that in those previous decades can be found some clues to understand the meaning of the responses indigenous and african descent population adopted toward the processes of independence in Paraguay and, ironically, their rapid vanishing from the official records. [Key words: borderland, mestizaje, indigenous peoples, Africans, Paraguay, Independence.]

Prácticamente desconocemos las características de la participación indígena y afrodescendiente en los procesos independentistas abiertos en el antiguo Virreinato del Río de la Plata en 1810 y el rol que esas poblaciones jugaron en la construcción de una emergente « soberanía popular». Las crónicas de la Independencia están marcadas por una paradoja: al tiempo que sitúan en esa fecha los inicios de la emancipación de los sectores subalternos, gradualmente les quitan protagonismo histórico hasta hacerlos desaparecer completamente como actores. Es razonable pensar que el colapso del régimen colonial y la consecuente igualación de las poblaciones «nacidas en el territorio » efectivamente contribuyeron a una progresiva pérdida de especificidad de « lo indígena » y « lo negro », lo que contrasta de manera radical con nuestra preocupación contemporánea por recuperar una agencia histórica subalterna en los procesos del pasado.

La paradoja mencionada adquiere mayores dimensiones en el caso del Paraguay donde, efectivamente, los afrodescendientes y especialmente los indígenas fueron progresivamente invisibilizados, pero donde la mayor parte de la población continuó hablando una lengua nativa, el guaraní. Podríamos decir 
que en este contexto, la pertenencia indígena se fundaba menos en hablar la lengua guaraní que en estar empadronado en un « pueblo de indios », situación jurídica de la que era conveniente escapar para evitar la explotación económica. La situación de los afrodescendientes era similar pues, si bien había desaparecido la obligatoriedad de pagar el marco de plata para los pardos, aún estaban en vigor las antiguas leyes españolas que perpetuaban su discriminación jurídica y social. Por otro lado, la esclavitud continuó vigente hasta su abolición en 1870 y el porcentaje de personas en esa condición (un cuatro por ciento durante los siglos XVIII y XIX), se mantuvo constante hasta dicha fecha.

Hasta el momento, las especificidades del caso paraguayo no han sido suficientemente indagadas. La historiografía tradicional ha sedimentado imágenes excesivamente sesgadas y anacrónicas del período independiente, en buena medida condicionadas por la situación geopolítica del Paraguay inmediatamente posterior a la guerra contra la Triple Alianza ${ }^{1}$. Lo cierto es que existe una serie de rasgos que contribuyen a resaltar la singularidad del caso paraguayo. La Independencia de 1811 fue liderada por los mismos hombres que meses antes habían denegado legitimidad a la Junta de gobierno de Buenos Aires y habían rechazado a las fuerzas de Manuel Belgrano. El « golpe » de la noche del 14 al 15 de mayo de 1811 se realizó sin derramamiento de sangre ni disparo de fusil y, llamativamente, Bernardo de Velazco, el gobernador depuesto, fue designado miembro del primer triunvirato que se organizó inmediatamente después.

El proceso iniciado posteriormente en Paraguay no podría ser considerado como una irrupción de "nuevos actores". Algunas evidencias indican que las poblaciones indígenas y afrodescendientes no se vieron sustancialmente afectadas por tal acontecimiento. El llamado de la Junta de Buenos Aires a aceptar al nuevo gobierno no sólo fue rechazado por Asunción sino que aparentemente tuvo escasa repercusión en las bases, como lo demuestran algunos documentos de la época. En su expedición al Paraguay, Manuel Belgrano, vocal de la Junta porteña, buscó interpelar a las poblaciones locales traduciendo proclamas y oficios al guaraní, lo que solamente le permitió lograr adeptos en la región localizada al sur del río Paraná, especialmente entre los indios guaraníes de las antiguas misiones, sujetos a la jurisdicción de Buenos Aires. Pero la situación no fue la misma en los pueblos bajo control de la administración paraguaya, de donde Belgrano debió retirarse derrotado militarmente.

Aquí sostenemos que, en lo inmediato, los grupos en cuestión no vieron mejorar sus condiciones de vida. Las mudanzas que los afectaron en el mediano plazo se relacionaron menos con un boom independentista que con una inercia, tanto de los cambios que se sucedieron tras la expulsión de los jesuitas en 1767-1768 como de las reformas iniciadas por el Estado colonial en las últimas décadas del siglo XVIII. Especialmente aquellas tendientes a liberalizar las actividades económicas, a romper con las distinciones de castas y a homogeneizar 
la lengua y las costumbres. Estas políticas, continuadas por los nuevos gobiernos, eran en realidad una reacción del Estado frente a un acelerado proceso de mestizaje al margen de toda « ley y moral », como indican algunos documentos, y a la necesidad de un reordenamiento territorial que se escapaba del control de los funcionarios en una zona geográfica particularmente inestable.

Este trabajo indaga sobre las características del proceso de independencia en la región del Paraguay, centrándose en las poblaciones indígenas y afrodescendientes. La primera parte analiza los efectos locales del discurso de la Junta de gobierno de Buenos Aires representada por su vocal, Manuel Belgrano. La segunda parte brinda detalles sobre las características y evolución de la situación poblacional y territorial del Paraguay desde las décadas anteriores, correspondientes al final del período colonial. Según suponemos, en esa dinámica previa se encuentran algunas de las claves para comprender las respuestas de la población indígena y afrodescendiente a los procesos de independencia en el Paraguay e, irónicamente, su rápido proceso de desaparición de los registros oficiales.

\section{ManUel Belgrano y la POBlación de la JURISDiCCión PARAgUaYa}

Ante el pedido de reconocimiento por parte de la Junta Provisional Gubernativa instalada en Buenos Aires a partir del 25 de mayo de 1810, la provincia del Paraguay respondió con un cabildo abierto dos meses más tarde ( 24 de julio) en el cual se resolvió rechazar a la Junta y reconocer al Supremo Consejo de Regencia, armando inmediatamente a « la numerosa juventud de la provincia » hasta el número de seis mil (Chaves 1959, p. 39). La provincia del Paraguay, con una población de alrededor de 120000 habitantes, seguía con los atributos que la caracterizaban desde tiempos coloniales: una ubicación periférica con respecto al centro que conformaba una frontera para el avance de las poblaciones indígenas no sometidas y del imperio portugués. Si bien un sector de la provincia inició un nuevo despliegue económico con la ganadería y el tabaco (estancado) acompañado por un extraordinario desarrollo comercial en manos de comerciantes foráneos, el grueso de la población siguió viviendo de la subsistencia de los productos de la chacra y utilizando el guaraní como lengua corriente (Cooney 1990, 2006; Kleinpenning 2003).

A principios de diciembre de 1810 Manuel Belgrano pasó por la zona y redactó una serie de cartas y proclamas cuyos destinatarios fueron los « nobles, fieles y leales paraguayos » y también los « Naturales de los pueblos de Misiones » (Museo Mitre, 14-08-08, f. 16v.) ${ }^{2}$. Entre la serie de documentos en cuestión importa destacar el Reglamento redactado el 30 de diciembre de 1810, cuando se encontraba en su campamento de Tacuary, que establecía una nueva organización política para los pueblos guaraníes. Belgrano ordenó que se sacaran 
copias para el gobernador de misiones y los cabildos indígenas, publicándolas en el primer día festivo, con explicación de los curas antes del ofertorio. Luego avanzó con sus tropas hasta la antigua estancia jesuítica de Paraguarí, a 68 kilómetros de Asunción. Allí fue derrotado por la tropa de Velazco el 19 de enero de 1811, quien lo hizo retroceder hasta la margen izquierda del río Tacuary. En ese sitio fue nuevamente atacado y derrotado el 9 de marzo por las tropas paraguayas al mando de Manuel Cavañas con 2500 hombres. Luego de esta derrota, Belgrano se vio obligado a firmar un armisticio y a retirarse con su ejército.

Ese acontecimiento marcó una división profunda en la provincia guaraní sujeta a la doble influencia de las jurisdicciones de Asunción y Buenos Aires. Dos de sus departamentos, Santiago y Candelaria, permanecieron en posesión de Paraguay y otros dos, Yapeyú y Concepción, bajo la órbita porteña. Luego de designar autoridades para estos departamentos y para Corrientes, Belgrano se dirigió inmediatamente con todas sus tropas en apoyo de los orientales que resistían a los regentistas de Montevideo. En su camino, incorporó dos compañías de milicias y 300 guaraníes misioneros, entre los que se encontraba Andrés Guacurary (más conocido como Andresito), quien más tarde se convertiría en uno de los líderes principales del movimiento artiguista (Wilde 2009).

Tanto en la ya referida proclama escrita en guaraní como en el Reglamento para el gobierno de los pueblos, Manuel Belgrano vuelca los principios básicos del ideario revolucionario cuya médula es la idea de una soberanía popular basada en derechos territoriales, los derechos de los « nacidos en el territorio americano ». Esta categoría inclusiva buscaba diluir la separación entre « indios» y «españoles» y construir el mismo sujeto al que interpelaba. En su Reglamento, Belgrano intenta traducir algunas de estas ideas a la práctica. A partir de entonces, los « indios » debían ser « en todo iguales a los españoles que hemos tenido la gloria de nacer en el suelo de América » (Museo Mitre, 14-08-08, f. 1r.-v.).

El Reglamento establecía sobre todo un modelo cultural que debía difundirse mediante la educación y una política lingüística. Así pues, Belgrano ordenaba en uno de sus artículos la creación de escuelas de " primeras letras, artes y oficios ». En otro aclaraba que no era su intención eliminar el idioma nativo de los pueblos sino facilitar la comunicación con los indios. Por ello prevenía que « la mayor parte de los cabildos se han de componer de individuos que hablen el castellano » en especial el corregidor, el alcalde de primer voto, el síndico procurador, y el secretario encargado de redactar las actas en lengua castellana (Museo Mitre, 14-08-08, f. 2v.).

Ya desde el título de este documento, «Reglamento constitutivo para el gobierno de los treinta pueblos », Belgrano daba a entender que los pueblos constituían en su conjunto una unidad autónoma independiente de Buenos Aires 
y Paraguay. La organización política interna de cada pueblo seguiría estando regida por el cabildo cuya cabeza, el corregidor, dependería directamente del gobernador de los treinta pueblos. A su vez, el Reglamento ordenaba que se mantuvieran los departamentos con sus subdelegados que « han de recaer [en los] hijos del país » (Museo Mitre, 14-08-08, f. 3r.). De la capital de cada departamento saldría un diputado para asistir al « congreso nacional » que, además de ser probo y tener buena conducta, « ha de saber hablar el castellano » (ibid.). La administración de la justicia quedaba a cargo del corregidor y los alcaldes, de acuerdo a la legislación vigente. Pero, más adelante, agregaba que éstos no podrían imponer castigo a los naturales y que, para toda queja, deberían recurrir a los jueces (Museo Mitre, 14-08-08, f. 3v.). Este orden social debía expresarse en la organización del espacio urbano. Así pues, señala el lugar donde debía ubicarse el cabildo, la Iglesia y los cementerios. Por último, ordenaba crear un cuerpo de milicia cuyo título sería « Milicia Patriótica de Misiones », en el que se nombrarían oficiales indistintamente « así los naturales como los españoles que vinieren a vivir á los pueblos, siempre que su conducta y circunstancias, los hagan acreedores á tan alta distinción [...] » (Museo Mitre, 14-08-08, f. 3r.). Mediante estas disposiciones, Belgrano buscaba estimular un sentimiento provincial en un distrito signado por la fragmentación.

También es destacable la concesión de autonomía para diversos poblados que hasta entonces se encontraban sujetos a las jurisdicciones misionera y correntina, como Curuzú Cuatiá y Mandisoví (Poenitz 1987). Así se autorizaba indirectamente el poblamiento criollo de tierras misioneras desocupadas, lo que había sido prohibido por el Marqués de Avilés algunos años antes. Como resultado se definía una orientación hacia la asimilación e igualación poblacional cuyo tono se manifiesta en el siguiente párrafo:

Que no habiendo ya distinción entre Naturales y Españoles, según lo que ha ordenado sabiamente la misma Excelentísima Junta, se tendrá el Pueblo con todos los fueros y privilegios que a los demás del Estado correspondan [...]. Que se harán venir las familias, sean de naturales o Españoles que estén dispersas en la jurisdicción, a poblarse, sin obligarles a que satisfagan los cuatro pesos del solar mientras no tuvieren facultades para ello. (Cuartel General de Curuzú Cuatiá, 16 de noviembre de 1810, AGN, Sala X, 2-4-15)

Puede observarse que el conjunto de disposiciones dictadas por Belgrano en su expedición a los diversos poblados de la región no sólo estaba destinado a legitimar al gobierno de la Junta porteña, sino que simultáneamente instituía un nuevo orden político basado en la « soberanía popular » y un tipo particular de actores, los « nacidos en la tierra », entre los cuales debían diluirse las diferencias impuestas durante la Colonia.

En la proclama a los «naturales » de principios de diciembre de 1810, Belgrano expresa claramente que su misión era 
[...] restituiros vuestros derechos de libertad, propiedad y seguridad de que habéis estado privados por tantas generaciones, sirviendo como esclavos a los que han tratado únicamente de enriquecerse a costa de vuestros sudores y aún de vuestra propia sangre [...] ya estoy en vuestro territorio, y pronto a daros las pruebas más relevantes de la sabia providencia de la misma Excelentísima Junta, para que se os repute como hermanos nuestros, y con cuyo motivo las compañías de vosotros que antes militaban en el ejército entre las castas, por disposición de nuestros opresores, hoy están entre los regimientos de patricios y arribeños [...]. (Museo Mitre, 14-08-08, 9r.-v.)

No es difícil descubrir en este discurso la herencia iusnaturalista del Antiguo Régimen que apelaba al territorio y la lengua como base de una identidad « natural » de las « gentes » que residían en los « pueblos » (Chiaramonte 1989, 2000; Quijada, Bernand y Schneider 2000) ${ }^{3}$. El discurso, y esencialmente la política, promovidos por Belgrano no eran completamente nuevos, ya que presentaban algunas continuidades con las ideas promovidas por la Corona desde fines del siglo XVIII. Tanto la orientación asimilacionista como la búsqueda de autonomía para los distritos locales, entre otras reformas, ya venían promoviéndose desde varias décadas antes. Como se sabe, la reunión de la gente dispersa de la campaña, la disolución de los límites étnicos o de castas y las reformas urbanísticas eran preocupaciones de los funcionarios tardocoloniales, especialmente después de la expulsión de los jesuitas (Wilde 1999; 2003).

La creación de milicias provinciales parece haber sido otro modo de dotar de nuevo sentido a una práctica preexistente. Como se sabe, entre los guaraníes existía una importante tradición miliciana, ya desde mediados del siglo XVII, muy conocida en la región platina por su apoyo a la Corona española, en sus acciones contra los portugueses. Sin embargo, esta participación disminuyó en el siglo siguiente con el impulso dado por los borbones a la formación de ejércitos regulares primero y el posterior ascenso de las milicias urbanas. Pero la asistencia de las milicias guaraníes a la Corona fue una constante desde mediados del siglo XVII y alcanza su apogeo durante el sofocamiento de los levantamientos comuneros en Asunción del Paraguay, ocurridos en la década de 1730. Hacia la primera década del siglo XIX la organización de las milicias misioneras estaba bastante deteriorada, pero Belgrano aparentemente se interesó en revitalizarla recuperando el imaginario de una antigua gloria militar, orientándola ahora al servicio de la patria.

Ritualidad, « lengua natural », territorio y milicia, parecen a simple vista elementos eficaces en la construcción de una legitimidad que articula lo nuevo y lo viejo. Sin embargo, en el relato y la política de Belgrano se perciben notables contradicciones y ambigüedades. Una de ellas residía en promover la asimilación preservando jerarquías de algunas figuras como los caciques. Otra consistía en otorgar autonomía a determinados distritos sin dejar de sujetarlos a aquellos que pretendía separar. Finalmente, se impulsaba la eliminación de la lengua guaraní mientras se la empleaba como medio para dirigirse a la población en cuestión. 
Estas contradicciones y ambigüedades se comprenden en el contexto de transición imperante. Las soluciones revolucionarias debían ajustarse a las tradiciones y usos locales preexistentes, entre las cuales el uso de la lengua nativa, el cacicazgo y la organización miliciana tenían un lugar preponderante. Éstas eran la base de la autonomía de los pueblos y ahora resultaban útiles para instaurar un orden civil y territorial de mayor envergadura.

\section{LEALTADES DIVIDIDAS}

Para el momento de la llegada de Belgrano a los pueblos, era palmaria la ineficacia de los mecanismos de control del Estado entre la gente de la campaña, acostumbrada a las interacciones personales de base reciprocitaria. Debe destacarse, en este ámbito, la presencia creciente de personajes caracterizados por lealtades móviles e identidades ambiguas y múltiples. Es probable que estos personajes fueran generando una suerte de arquetipo que servía incluso de modelo de acción para varios sujetos que intentaban escapar a los controles del Estado y que eran generalmente estigmatizados y perseguidos por las autoridades. En este sentido, puede decirse que, detrás del modelo de "ciudadano virtuoso" que buscaba imponer el discurso revolucionario hundiendo sus raíces en la tradición tardocolonial, se ocultaba un conjunto de prácticas socioculturales, también heredadas de la época colonial, que operaban eficazmente como fundamento para la acción de buena parte de los habitantes de la campaña.

Desde años antes de la llegada de Belgrano, el distrito guaraní se encontraba dividido desde un punto de vista político-administrativo en tres realidades bastante diferenciadas, correspondientes a las influencias de Asunción, Buenos Aires y Portugal. La permanente inestabilidad de las fronteras establecidas por las autoridades porteñas, paraguayas y portuguesas, convertían al distrito misionero en un escenario propicio para la circulación de gente y de información que no poseían referencias estatales claramente definidas.

Esta situación territorial no era nueva sino que se venía profundizando desde las décadas anteriores y que abarcaba una región mucho más amplia. Una de las características fundamentales de ese espacio altamente dinámico era la movilidad poblacional, lo que traía como consecuencia permanentes interacciones entre poblaciones con diferentes orígenes étnicos, que desarrollaban circuitos de intercambio económico, social y cultural en los que a veces intervenían los gobiernos locales. Ya desde fines del período colonial, esta amplia región de frontera fue objeto de políticas estatales destinadas a controlar los mencionados circuitos y a sujetar a la población que deambulaba al margen de toda ley.

A diferencia de los pueblos bajo la jurisdicción porteña, los de la paraguaya conservaron un sistema de organización comunitaria del trabajo, heredado de la 
época jesuítica. Con el objeto de evitar la difusión de los conflictos del Río de la Plata, el Paraguay, una vez que obtuvo el reconocimiento porteño de su Junta superior gubernativa, sostuvo una política aislacionista en la región. Desde su asunción como dictador en 1814, José Gaspar Rodríguez de Francia, defendió esa política a ultranza. En lo que respecta a la población indígena, se optó por mantener el sistema de comunidad en los pueblos misioneros aunque bajo la estricta supervisión del Estado. Previamente se había eliminado completamente la autoridad temporal de los clérigos, obteniendo la total subordinación de la Iglesia (Maeder 1992; Whigham 1995, 2002).

La situación de los pueblos controlados por Buenos Aires era muy diferente. Lo que define su fisonomía político-administrativa es, sin lugar a dudas, la eliminación parcial del régimen de comunidad por Avilés entre 1801 y 1803. Según informan las fuentes, esta medida trajo problemas de desabastecimiento en varios pueblos. En 1808, a pedido del corregidor y cabildo de Yapeyú, se otorgó licencia para hacer una vaquería en los campos de la Banda Oriental del Uruguay, dando ración de carne a mil familias del pueblo que « no poseen ganado, ni arbitrio con que comprarlo, por haber cesado el sistema de comunidad». Además, el funcionario proponía mandar una partida de tropa de seis hombres y un cabo de auxilio para que no sean invadidos por los " infieles » (Carta de Agustín de la Rosa, pueblo de Apóstoles, 3 de noviembre de 1808, AGN, Sala IX, 18-3-7).

La situación política, demográfica y territorial de la primera década del siglo XIX resulta de una serie de transformaciones ocurridas durante el siglo anterior. Las próximas secciones se concentran en el abordaje de dicho período (Figura 1).

\section{UNA PROVINCIA ASEDIADA: LA JURISDICCIÓN PARAGUAYA AL FINAL DE LA COLONIA}

Para mediados del siglo XVIII, Paraguay era una provincia de frontera ubicada en las márgenes del virreinato del Perú. Ocupaba desde fines del siglo XVII una estrecha franja al este del río Paraguay enmarcada al sur por el río Tebicuary y al norte por el Manduvirá. En 1715 se fundó Curuguaty, en el extremo este de la provincia, un enclave yerbatero alejado unos trescientos kilómetros de Asunción. Los límites de la provincia se hacían más estrechos si tenemos en cuenta que en su territorio existían diez pueblos de indios bajo el control del clero secular o de los franciscanos ${ }^{4}$ además de las estancias que las órdenes religiosas poseían con población esclava: los jesuitas en Paraguarí, los dominicos en Tavapy y los mercedarios en Areguá. Al sur del río Tebicuary se extendía el dominio jesuítico con sus treinta misiones, un espacio que la orden había logrado desanexar del control civil de la provincia paraguaya, aunque una parte dependiera del 


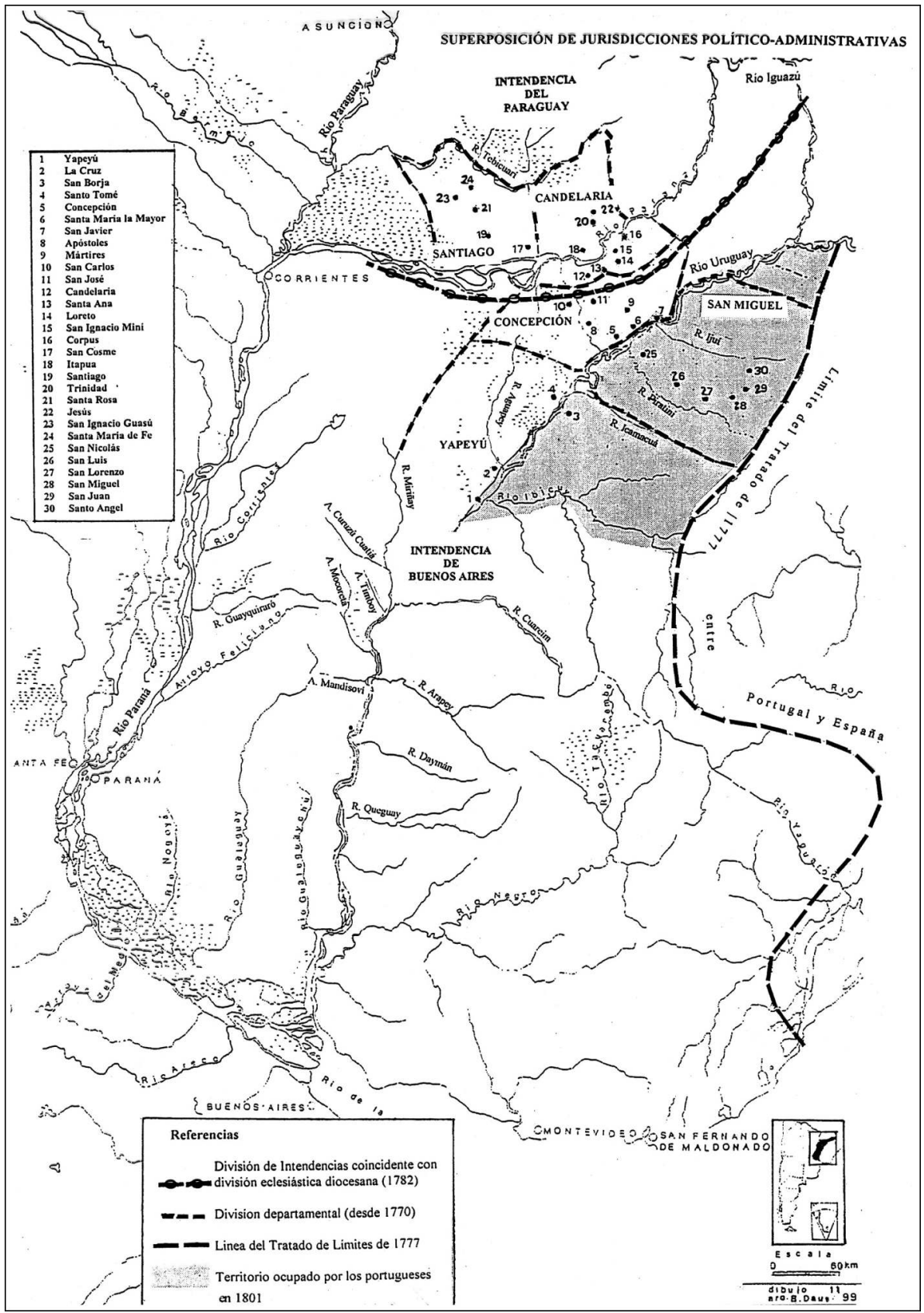

FIG. 1 - Superposición de jurisdicciones politico-administrativas posterior a la expulsión de los jesuitas (según Wilde 2009, p. 268). 
obispado asunceno. Al norte del río Manduvirá el territorio estaba controlado por los mbayás, chanés y guanás, pueblos indígenas considerados en la historiografía tradicional como los « temidos chaqueños ». Al oeste del río Paraguay, otros pueblos indígenas como los payaguás, mocobíes y abipones se movían con bastante libertad. Hacia el este se encontraba el grupo genéricamente identificado como guaraní montés (cainguá), una porción del cual había sido incorporada a pueblos de misión.

Los diversos grupos no sometidos aparecen en las fuentes de la época como verdaderos peligros para la población asuncena, manteniéndola en constante alerta. La situación no cambió sustancialmente durante todo el siglo xviII, lo que puede interpretarse como la causa más palpable de la " pobreza » reinante en la provincia del Paraguay, tal y como la caracteriza el gobernador García Ros: « La provincia es dilatada pero muy pobre, siendo la más gentil, amena y florida que habrá en este reino y si no fuera por las frutas silvestres que dan los montes gran parte del año perecería de hambre, no sólo los miserables indios, pero la mayor parte de la plebe » (citado por Trelles 1867, p. 134).

Las revueltas comuneras ocurridas entre 1721 y 1735 profundizaron una situación ya crítica. En un informe de diciembre de 1733, el obispo del Paraguay, Fray José de Palos, advertía que, si las revueltas continuaban y los soldados abandonaban todos sus presidios, « avisarán los payaguás a los mbayás para que entrando éstos por Tobatí y la Cordillera, asalten ellos por el río con sus canoas esta ciudad y valles, sin perdonar inocencia, con que quedará perdida la provincia » (AGI, Charcas, 323, Informe del obispo Palos, 16 de diciembre de 1733).

Fue el gobernador Rafael de la Moneda quien dio impulso nuevamente a la fortificación de la frontera. En su informe al rey de 1742 especificaba que había edificado ocho fuertes en sitios ventajosos « para observar y detener la invasión de los infieles », además había mandado cavar dos fosos de más de 500 varas cada uno con sus respectivos parapetos y fuertes « que han cerrado la entrada a los valles de la Provincia ». Según el gobernador, estos seguros hicieron que los vecinos volvieran a poblar « la mejor porción y más útil de la provincia » (AGI, Charcas, 374, Informe del gobernador Moneda al Rey, 10 de marzo de 1742).

Entre los emprendimientos más importantes de Rafael de la Moneda se encontraba la fundación de un pueblo con población exclusivamente "parda libre » a 30 kilómetros de Asunción costa arriba, con el fin de frenar las incursiones de los mbayás. Por una carta que envía al obispo pidiéndole que nombre un curato en propiedad, sabemos que el pueblo estaba habitado por alrededor de 500 personas en más de cien casas (AGI, Charcas, 374, Moneda al obispo Paravicino, 27 de julio de 1743). La nueva localización fue llamada significativamente Emboscada o Camba Reta (lugar/país de negros, en guaraní) ${ }^{5}$. Durante el gobierno del mismo gobernador se repartieron setenta mercedes reales de tierra, entre puestos de estancias y tierras de labor, lo que 
representó un aumento considerable con respecto al período anterior. Todas ellas se ubicaban entre Asunción y Emboscada, logrando asegurar una porción de « territorio recuperado » (Telesca 2009b).

Sin embargo, la situación de pobreza continuaba, como lo indica el gobernador Larrazábal en su informe al virrey del Perú en 1747: « Esta provincia está poblada por la más pobre gente que conozco en cuanto tengo paseado del reino. No es laboriosa y mucho menos industriosa. Esta natural desidia y la continua carga de guardias y destacamentos que de unas y otros hay treinta y dos en el país, rodeado de enemigos por todos sus costados, no les permite salir a los más de la mendicidad » (AGN, Sala IX, 5-3-7, Informe de Larrazábal al virrey, 20 de septiembre de 1747).

Según se infiere de esta cita y de otros informes y relatos de la época, la defensa de la provincia a costa de los mismos provincianos era una de las causas principales de la pobreza. En las décadas sucesivas, los crecientes problemas derivados de la situación de frontera impulsarían la progresiva incorporación de la gente de la campaña a los presidios durante períodos prolongados gestando lo que varios autores han caracterizado como una "sociedad militarizada " (Romero de Viola 1987; Garavaglia 1987; Boidin 2006).

En síntesis, pobreza y militarización se afirmarían como dos características marcantes de la provincia del Paraguay durante el siglo XIX. Aunque las elites locales no desaparecieron, una población eminentemente rural y campesina se fue homogeneizando en base a tales características económicas y políticas comunes. A su vez, la lengua guaraní se expandiría como el medio fundamental de comunicación y socialización. Tal realidad ofrecía a la población indígena y afrodescendiente la posibilidad de diluir las diferencias para ser reconocida bajo la categoría jurídica de « español ». No es casual que en este período se consolide un proceso de desaparición de las poblaciones en cuestión de los registros oficiales.

\section{LA INVISIBILIZACIÓN DE LA POBLACIÓN INDÍGENA Y AFRODESCENDIENTE}

Para 1761 la población total de la provincia ascendía a 85138 personas, incluyendo los pueblos de indios bajo el control jesuítico, aunque estos últimos no participaban de la vida económica-social de la provincia, pues no estaban encomendados a los vecinos del Paraguay. Podría decirse entonces que la población real era de apenas 38575 personas distribuidas en el estrecho territorio bordeado por los ríos Manduvirá al norte y Tebicuary al sur.

Esta situación cambiaría drásticamente después de la expulsión de la Compañía de Jesús en 1767-1768, acontecimiento que desencadenó un notorio proceso de transformación demográfica y territorial, como lo pone de manifiesto el siguiente cuadro (Figura 2): 


\begin{tabular}{l|r|r|r|r|r}
\multirow{2}{*}{} & \multicolumn{2}{|c|}{1761} & \multicolumn{2}{c|}{1782} & diferencia \\
\cline { 2 - 6 } & & \multicolumn{1}{c|}{$\%$} & & \multicolumn{1}{c}{$\%$} & \multicolumn{1}{c}{$\%$} \\
\hline Misiones jesuitas & 46563 & 54,7 & 20383 & 21,1 & \\
Pueblos de indios & 5358 & 6,3 & 9788 & 10,2 & \\
Población indígena total & 51921 & 61,0 & 30171 & 31,3 & $-41,9$ \\
Población no indígena & 33217 & 39,0 & 66355 & 68,7 & $+99,9$ \\
\hline TOTAL & 85138 & 100 & 96526 & 100 & $+13,4$
\end{tabular}

FIG. 2 - Comparación poblacional entre 1761 y $1782{ }^{6}$ [Fuente: Visita a su diócesis del obispo Torre (1761) y Aguirre (1949)].

En los veinte años contemplados, la población total creció un 13,4 \% mientras que la población no indígena lo hizo en un 99,9\%. No podemos ser totalmente taxativos, pero es razonable afirmar que una gran parte de la población de las ex reducciones jesuíticas pasó a engrosar la población considerada como española. Llama la atención también que el descenso de la población de los 13 pueblos jesuíticos correspondientes al obispado de Asunción sea aún mucho más pronunciado que el de los que pertenecían al obispado de Buenos Aires. Datos proporcionados por Maeder (1992) muestran que entre 1768 y 1783 la población de los primeros pasó de 41050 a 19 012, mientras que la población de los segundos descendió de 47778 a 37070 . Es decir que mientras que los dependientes del obispado asunceno perdieron más del $50 \%$ de su población, los otros sólo perdieron el $20 \%$. Si ampliamos el anterior cuadro incluyendo los censos de 1799 y 1846 obtenemos los datos de la Figura 3.

\begin{tabular}{l|c|c|c|c|c|c|r|c}
\multirow{2}{*}{} & \multicolumn{2}{|c|}{1761} & \multicolumn{2}{c|}{1782} & \multicolumn{2}{c|}{1799} & \multicolumn{2}{c}{1846} \\
\cline { 2 - 9 } & & $\%$ & & $\%$ & & $\%$ & & $\%$ \\
\hline Población indígena & 51921 & 61,0 & 30171 & 31,3 & 29570 & 27,4 & 1200 & 0,5 \\
Población no indígena & 33217 & 39,0 & 66355 & 68,7 & 78500 & 72,6 & 237664 & 99,5 \\
\hline TOTAL & 85138 & 100 & 96526 & 100 & 108070 & 100 & 238864 & 100
\end{tabular}

FIG. 3 - Comparación poblacional entre 1761 y $1846^{7}$ [Fuente : Visita a su diócesis del obispo Torre (1761), Aguirre (1949), Maeder (1975) y Williams (1976)].

Si bien a fines del siglo XVIII se produjo una muy pequeña inmigración desde Buenos Aires y Europa, ésta se cortó con el movimiento de la Independencia primero, en 1811, y con el gobierno del Dr. Francia más tarde (1814-1840). Dicho proceso se vio acelerado por el avance de la población española hacia los pueblos de indios. En 1781, Juan Bautista Achard, protector de naturales, se queja al gobernador Melo de Portugal sobre la introducción de españoles en dichos pueblos. Además de insistir en los daños morales que esto ocasiona, se centra Achard en los perjuicios económicos, ya que los españoles introducen sus ganados mayores en las sementeras de los pueblos con el beneplácito de 
los mismos indios, quienes arriendan a los españoles sus campos. Se crea así otro circuito económico: los indígenas no tienen que trabajar para el pueblo sino que viven de los arriendos. Al mismo tiempo esta introducción de españoles genera «muchos pecados, muchas bastardías, y pocas legitimidades en la generación de los pueblos » (ANA, SH, 147.6). De esta manera, los pueblos de indios se encuentran reducidos a su mínima expresión y no tienen lugar donde desarrollarse. Además, los españoles, una vez instalados, « se van conglobando de generación en generación en las tierras de los indios y sus descendientes van ocupando más lugar y lugares en perjuicio de los indios y enormísimos daños de los pueblos ». Cuando el gobernador le pide al defensor de naturales que especifique en qué pueblos se da esta situación, Achard aclara que en «los pueblos que más se verifican los abusos pre-alegados son Tobatí, Altos, Yaguarón, Itá y Guarambaré. Y los demás, cual más cual menos, padecen apropiación de su cortedad de territorio ». Aclara que Caazapá, Yuty, San Joaquín y San Estanislao se ven libres de este asecho porque se hallan muy alejados ${ }^{8}$. Como remedio para esta situación, Achard propone al gobernador que envíe a todos estos intrusos a las nuevas fronteras que se iban abriendo al norte y al sur « donde sirviesen de atajo a los enemigos, de aumento y extensión a la Provincia » (ANA, SH, 147.6.).

No es razonable atribuir la situación demográfica a un «genocidio indígena $"{ }^{9}$. Todo parece indicar, más bien, que los indígenas, antes que desaparecer, pasaron a ser categorizados de otra manera. Ellos mismos asumieron este "salto categorial» como una ventaja, en la medida que les permitía salir de la categoría de « indios » para ser tenidos por « españoles » en los censos; españoles, importa aclararlo, que hablaban mayoritariamente la lengua guaraní. De modo que no sería del todo preciso referir a este proceso como una "mestización » de la sociedad paraguaya, en el que se impusieron parámetros culturales dominantemente españoles, sino de una verdadera guaranización de la misma, que se mantuvo en las décadas posteriores ${ }^{10}$. Tanto españoles como indígenas y afrodescendientes veían ventajas en la confusión categorial y la interrelación que mantenían entre sí: los españoles lograban hacerse con más tierra para sus sementeras y ganados, y los pueblos de indios y afrodescendientes dejaban de ser discriminados como tales sin, por ello, abandonar completamente sus antiguas costumbres.

A diferencia de los indígenas que vivían en los pueblos de indios bajo control secular o franciscano, los de la órbita de la Compañía de Jesús no estaban encomendados a personas físicas sino a la Corona. Esto significa que no existían allí encomenderos que reclamasen por sus indios fugados. Los nuevos latifundistas veían en ellos mano de obra disponible, y - antes que reconocerlos como indígenas quedando obligados a devolverlos a sus pueblos originarios preferían asumirlos como « españoles » pobres, lo que los hacía directamente aprovechables para el trabajo. 
A este panorama socio-económico debemos agregar información correspondiente a la población descendiente de los esclavizados. Los afrodescendientes no eran un grupo al margen del resto de la sociedad. El Paraguay era, como el resto del Virreinato del Río de la Plata, una sociedad con afrodescendientes. Sabemos que la población parda no era tan reducida como se pensaba. Velázquez (1965, p. 65) afirma que " en cuanto a los esclavos, pese al asiento de negros establecido en Buenos Aires un siglo antes, su número sigue siendo exiguo en el Paraguay ». Si bien es cierto que para 1782 el mundo pardo representaba el $11,3 \%$ de la población paraguaya, en la ciudad de Asunción ese porcentaje se elevaba al 54,7 \% (el 23,4 \% eran esclavos y el 31,3 pardos libres).

La población afrodescendiente en Paraguay, aunque se redujo en el siglo XIX, mantiene durante este período un porcentaje aún importante dentro del total de la población de la provincia (Figura 4).

\begin{tabular}{l|r|r|r|r|r|r}
\multirow{2}{*}{} & \multicolumn{2}{|c|}{1782} & \multicolumn{2}{c|}{1799} & \multicolumn{2}{c}{1846} \\
\cline { 2 - 7 } & & \multicolumn{1}{c|}{$\%$} & & \multicolumn{1}{c}{$\%$} & & \multicolumn{1}{c}{$\%$} \\
\hline Libres & 6793 & 7,1 & 7948 & 7,4 & 8416 & 3,6 \\
Esclavos & 3953 & 4,1 & 4598 & 4,3 & 8796 & 3,8 \\
\hline TOTAL & 10746 & 11,2 & 12546 & 11,7 & 17212 & 7,4
\end{tabular}

Fig. 4 - Población parda de 1782 a 1846 [Fuente: Aguirre (1949), Maeder (1975) y Williams (1976)].

Si bien el porcentaje de la población esclava se mantiene estable durante estos sesenta años, no ocurre lo mismo con la población parda libre, cuyo porcentaje se reduce a la mitad. Sin llegar a los extremos que nos presentaban los datos sobre la población indígena, aquí también nos encontramos con que una buena cantidad de pardos libres pasan a engrosar el grupo de los españoles/paraguayos.

Existe un caso en el que la población parda libre aumentó. Se trata del pueblo de Emboscada, formado en 1741, que albergaba pardos libres al estilo de pueblo de indios con el beneficio de no pagar el tributo del marco de plata. La población de Emboscada que en 1782 representaba el 11,4\% de la población parda libre total de la provincia, en 1846 ascendía al 28,8\%, como lo muestra la Figura 5.

\begin{tabular}{l|r|r|r|r|r|r} 
& \multicolumn{2}{|c|}{1782} & \multicolumn{2}{|c|}{1799} & \multicolumn{2}{c}{1846} \\
\cline { 2 - 7 } & & $\%{ }^{11}$ & & $\%$ & & $\%$ \\
\hline Pardos libres & 773 & 11,4 & 897 & 11,3 & 2422 & 28,8 \\
Esclavos & 2 & & 35 & & 2 & \\
Españoles/blancos & & & 108 & & 994 & \\
Indígenas & & & 96 & & & \\
\hline TOTAL & 775 & & 1136 & & 3418 &
\end{tabular}

FIG. 5 - Población del pueblo de Emboscada de 1782 a 1846 [Fuente: Aguirre (1949), Maeder (1975) y Williams (1976)]. 
Si dejáramos de lado a la población de Emboscada, la población parda libre en 1799 representaría el 6,5\% y en 1846 sólo el 2,5\% de la población total. El último cuadro nos revela que más de un cuarto de la población parda libre del Paraguay vivía en Emboscada, y que incluso la población considerada « española» en Emboscada pasa de un 9,5\% en 1799 a un $29 \%$ en 1846. No es impensable que, de no haber ocurrido la guerra contra la Triple Alianza, Emboscada también hubiera sucumbido a la tendencia general verificable en el resto de la población parda libre e incluso indígena.

La información previa es relevante para el análisis de la participación de los indígenas y afrodescendientes en el proceso de independencia. Nos alerta sobre el riesgo de detenernos exclusivamente en aquellos sectores sociales que en las fuentes de la época eran considerados como tales. Especialmente las Figuras 3 y 4 señalan claramente una "trampa categorial» que sólo se descubre considerando la continuidad en el siglo XIX de procesos iniciados en las últimas décadas del siglo XVIII.

También debe considerarse la mezcla cultural y biológica como un elemento importante de este proceso. A fines de 1793, el gobernador Joaquín de Alós manifiesta una queja ante el rey, mientras visitaba el pueblo de indios de Yaguarón. Dice que los indígenas de los pueblos de indios se casaban «por lo común con negras y mulatas, esclavas y libres, de cuyo desorden dimanan considerables perjuicios y atrasos a los mismos pueblos » (AGN, Biblioteca Nacional, manuscrito 1688). De hecho, en la acusación del defensor de naturales, además de españoles se queja también que mulatos y negros se introducen en las reducciones y pueblos de indios.

El gobernador Alós protestará de cómo los curas permiten casamientos tan desiguales, sin embargo de la misma carta podemos sacar otras realidades que no presentan una radiografía de la sociedad. En este caso fue un artesano viudo que se escapó del pueblo de Yaguarón y se acogió en la casa de una mujer española donde conoció a una de sus esclavas y se casaron. La queja de Alós es que los españoles « apadrinan y mantienen años y años [a los indígenas de los pueblos] por el interés del servicio $»{ }^{12}$. El gobernador es consciente que este actuar de los indígenas no es gratuito sino que constituye una estrategia muy utilizada por los mismos para dejar de estar sujetos al pueblo: « Ésta es la causa, dice Alós, porque los indios e indias se desertan de sus orígenes y contraen nupcias tan desiguales privando a las comunidades de la labor de sus manos y a su Majestad de los tributos ».

Pero acá no se agota la agencia indígena sino que las mujeres que quedan en el pueblo, ante la escasez de varones con quien casarse, afirma el gobernador que se entregan «al comercio con los indios casados, o con los españoles circunvecinos, después de lo cual, cuando llegan a tener prole, tratan de acreditar con información ser habida de español para que se declare por libre del tributo, y como no faltan testigos para todo regularmente, éste es el recurso ordinario con que incomodan al gobierno $»$. 
Alós es consciente que, de esta manera, los pueblos desaparecerán y con ellos los indígenas que los habitan, y si le escribe directamente al rey es porque este problema « es cuasi general en la Provincia ». El 0,5\% de población indígena que indica el censo de 1846 nos está mostrando que esta salida indígena se había prolongado por las siguientes décadas.

\section{UNA NUEVA POBLACIÓN PARA UN NUEVO TERRITORIO}

La sociedad paraguaya se vio totalmente transformada hacia fines del siglo XVIII. Nos encontramos ya con una población mayoritariamente autodefinida como «no indígena » (más del $70 \%$ para 1799) y ocupando un territorio dos veces más grande que el que tenía en 1760. Al mismo tiempo, vemos surgir una elite terrateniente-ganadera interrelacionada con el grupo de los antiguos encomenderos.

La gran cantidad de personas que se integró a la porción de la población considerada como «española » implicó una fuerte presión por el acceso a la tierra. Es más, si al tiempo del éxodo guaraní de los pueblos de indios a la campaña paraguaya tras la expulsión de los jesuitas no se hubiera dado una conquista de nuevos territorios, hubiésemos asistido probablemente a una eclosión social. En otras palabras crecimiento demográfico y territorial se dieron al mismo tiempo y luego de la expulsión de la Compañía de Jesús del territorio de la Corona española (ver Figura 6).

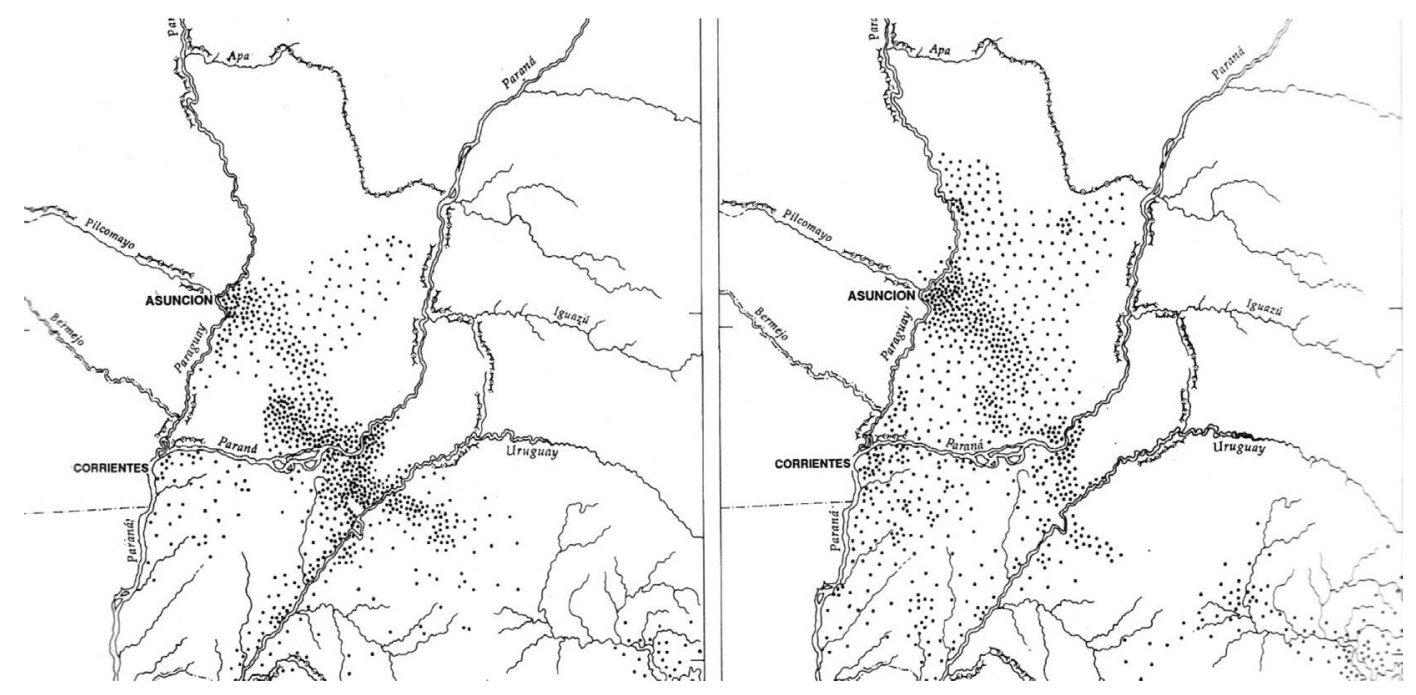

FIG. 6 - Espacio ocupado y densidad poblacional, comparación 1750 y 1790 [Fuente: Maeder y Gutiérrez 1995, p. 57]. 
Las nuevas poblaciones se fundaron tanto en el norte (Villa Real de la Concepción en 1773) como en el sur (Villa del Pilar de Ñeembucú en 1779). La nueva tierra conquistada fue repartida entre una pequeña elite, generándose el nacimiento de lo que podríamos llamar una mentalidad latifundiaria ${ }^{13}$. Ya antes de la expulsión de los jesuitas y luego de las revueltas comuneras las grandes estancias habían hecho su aparición, al margen de las que tenían las congregaciones religiosas. Entre 1741 y 1771 se repartieron 102 mercedes reales para puestos de estancias de las 258 repartidas en total por los diferentes gobernadores (Telesca 2009b). Sin embargo, las dimensiones de estos puestos serán inferiores a las nuevas estancias en los territorios reconquistados.

Esta reconquista de territorios con abundante mano de obra disponible potenció la cosecha y comercialización del principal rubro de la economía paraguaya, la yerba mate. Whigham (2009, pp. 171-172) nos muestra cómo las exportaciones de yerba pasaron de 27,000 arrobas en 1776 a más de 160000 diez años después. Este despegue económico sin lugar a dudas se vio favorecido por la creación del Virreinato del Río del Plata en 1776, el reglamento del libre comercio de 1778 y la creación de la Real Renta del Tabaco al año siguiente. Este último monopolio del tabaco por parte de la Corona significó por primera vez para la provincia del Paraguay, la entrada de moneda metálica en gran cantidad y en forma continuada (Caballero Campos 2006). La provincia ve surgir de esta manera una multiplicidad de nuevos comercios y una nueva elite comercial, fundamentalmente de fuera de la provincia, pero que hace rápidos lazos con la elite criolla.

Susnik ha señalado la existencia de un marcado « regionalismo nacional » ya en tiempos previos a la Independencia. Expresa la autora que « desde la época de la revolución comunera, los labradores con sus "ranchos de paja", los campesinos-braceros con sus campos de arriendo y los granjeros con sus "lances de casas y corrales", constituían el $60 \%$ de la población, caracterizándose ésta por su conservatismo económico, su tradicionalismo de costumbres, su conformismo vivencial, su identificación con la "provincia patria" en el sentido de un exclusivismo societal y comunicativo, siempre una conciencia nacional, latente o abierta [...]» (Susnik 1992, p. 7).

La « identificación » con una « provincia patria » es un punto que aún resulta controvertido. Como ya vimos en la Figura 2, tras las revueltas comuneras, y todavía en 1761, eran los indígenas los que representaban el $61 \%$ de la población. Pero tras la expulsión de los jesuitas los porcentajes se invierten, y resulta verdaderamente difícil medir el grado de identificación que los indios mantienen con su " provincia patria ». Como quiera que sea, este punto es relevante para indagar sobre las autonomías locales y la participación más amplia que los pueblos tuvieron después de la Independencia en las nuevas instituciones ${ }^{14}$.

En la apretada síntesis previa hemos sugerido que los cambios que se sucedieron en el último cuarto del siglo XVIII (demográficos, territoriales y 
económicos) modificaron de una manera singular a la provincia del Paraguay. El hecho de que estos cambios ocurrieran en un lapso relativamente breve de tiempo, precisamente anterior a 1811, puede darnos una primera explicación sobre el por qué, a nivel social, convenía poco dar cabida a las ideas ilustradas que ya circulaban en la parte meridional de la región, de la cuales Manuel Belgrano era defensor.

\section{LOS SUBALTERNOS Y LA INDEPENDENCIA: ESTRATEGIAS DE DESVANECIMIENTO}

En las páginas previas hemos propuesto una interpretación del proceso de independencia paraguayo, vinculándolo con los antecedentes del período colonial tardío. Sugerimos que los acontecimientos desencadenados a partir de 1810-1811 precipitaron un proceso ya vigente de reformas cuyo resultado inmediato fue la separación de la antigua gobernación del Paraguay, tanto en términos territoriales como poblacionales. Entonces comenzaron a expresarse divisiones en el imaginario de diferentes miembros de la elite revolucionaria que, a su vez, provocaron respuestas locales divergentes. Por un lado, aquellos que, como Belgrano, se inspiraron en una visión ilustrada que continuaba el camino marcado por las últimas ordenanzas ilustradas de la Corona española; por otro lado, sectores de la elite asuncena que defendían la conservación de determinados privilegios de la sociedad colonial y, por lo tanto, la sujeción de la población indígena y negra a las antiguas leyes y estructuras. Esa población reaccionó con estrategias particulares a tales imaginarios (Telesca 2009a).

En la jurisdicción porteña varios líderes indígenas se hicieron eco del discurso de Belgrano y consolidaron sus carreras militares individuales en apoyo de Buenos Aires (Wilde 2009, p. 316) ${ }^{15}$. Por contraste, las poblaciones sujetas a las nuevas autoridades instaladas en Asunción a partir de mayo de 1811 tomaron otro derrotero. Luego del 14 y 15 de mayo de 1811 se forma un triunvirato que, a fines de ese mes, convoca a un congreso general para el 17 de junio a fin de « establecer el régimen y gobierno que debe observarse en adelante y comentar la forma de unión y relaciones que esta provincia haya de tener con la de Buenos Aires » (Francia 2009, p 75). En las primeras resoluciones no se mencionan a los indígenas ni a los afrodescendientes en particular, sino en forma genérica a « los infelices paraguayos [que] ya han padecido bastante en cerca de tres siglos en que han sido indignamente vilipendiados y postergados $»$ (ibid., p. 82) ${ }^{16}$.

Las resoluciones posteriores siguen en un tono parecido. Más tarde, en enero de 1812, la Junta ya reducida a tres miembros bajo el control de Fernando de la Mora, exime a los indígenas de los pueblos de indios del pago del tributo anual y ratifica la abolición de la encomienda, resuelta por Real Cédula de 1803, que no se había cumplido cabalmente. La organización del gobierno de la provincia se volvió a someter al Congreso de 1813 en donde participaron mil diputados 
provenientes de todo el Paraguay. No se ha encontrado el acta con las firmas originales de dicho encuentro, por lo que no podemos saber a ciencia cierta si los indígenas de los pueblos de indios realmente participaron. Susnik (1992, p. 24) afirma que tal representación indígena existió, pero no especifica su fuente. Por su parte, el escocés John Parish Robertson describe en sus Cartas sobre el Paraguay la presencia de un indio tapé alcalde, pero no señala su procedencia ni que estuviera acompañado de otras autoridades indígenas (Robertson y Robertson 1988, pp. 39-41). La presencia indígena en los congresos de 1813 y 1814 aún debe ser esclarecida. De confirmarse, no se trataría de un hecho baladí, pues en esas oportunidades se definirían los destinos del gobierno paraguayo independiente de las décadas posteriores y un reconocimiento de ciudadanía para el indígena.

En el primer Congreso General, realizado los días 17 y 20 de junio de 1811 se registran 259 firmas, entre las cuales figuran las de los administradores de Yaguarón y de Altos, pero no de los otros pueblos de indios. Si bien la composición de los congresistas para los siguientes congresos cambió, y la elección fue popular (podían votar los varones casados o los solteros mayores de 23 años), tampoco se registra en la documentación una convocatoria a los pueblos de indios ${ }^{17}$.

Parece inconsistente suponer que los indígenas fueron reconocidos como iguales en la segunda década del siglo XIX, cuando los pueblos de indios persistieron como realidad jurídica en el Paraguay hasta 1848. En esa fecha, Carlos Antonio López declaró "ciudadanos » a los « indios naturales de los veintiún pueblos del territorio de la República » (ANA, SH, 282.24). Lo mismo puede sostenerse para el caso de la población negra, ya que, cuando se ordenó la supresión de las órdenes religiosas (en 1824) y el Estado se quedó con los bienes de las mismas, los esclavos de las órdenes pasaron a constituirse en la esclavatura del Estado, al igual que los esclavos de aquellos que sufrían la confiscación de sus bienes por parte del régimen. Resulta irónico constatar en un catecismo utilizado para la enseñanza en las escuelas primarias durante el gobierno del Dr. Francia, en el párrafo en el que se le pregunta al niño sobre los hechos que prueban la bondad del sistema de gobierno, éste debe responder « el haber abolido la esclavitud sin perjuicio de los propietarios » (Chaves 1985, p. 198).

La población esclava, que a mediados del siglo XIX rondaba el $4 \%$, tuvo que esperar hasta la constitución de 1870 en que se decretó la abolición de la esclavitud. El 1 de enero de 1843, se había puesto en práctica la «libertad de vientres », según la cual los nacidos a partir de la fecha serían considerados « libertos» y luego de cumplir los veintitres y veinticuatro años, mujeres y varones, respectivamente, ganarían la libertad. Pero la guerra contra la Triple Alianza llegó más rápido. La población afrodescendiente libre, si bien ya no estaba obligada a pagar el marco de plata ${ }^{18}$, también debió, al igual que con la fundación de Emboscada en 1741, ir a poblar Tevegó en 1813, población establecida al norte de Villa Real de la Concepción con la función de 
ser antemural de los embates portugueses y de las poblaciones indígenas no sometidas. A diferencia de Emboscada, Tevegó duró sólo diez años.

Aunque Paraguay experimentó un cambio político en 1811 poniendo en marcha un nuevo régimen republicano, los antiguos actores subalternos - indígenas y afrodescendientes - continuaron sufriendo la marginación de antaño. Las estrategias que estos sectores debieron poner en práctica tampoco se diferenciaron sustancialmente de la última etapa de la época colonial. La fórmula consistía en desaparecer para conservarse. En efecto, estas poblaciones seguirían trabajando hasta su « ciudadanización », primero en las « estancias de la patria » y luego en las nuevas industrias estatales que se instalarían en el país (Rivarola 1994). El proceso de desvanecimiento que habían iniciado para evitar la exclusión e integrarse a las transformaciones económicas, políticas y sociales de la región, fue continuado, a nivel imaginario, por una historiografía oficial que directamente tendió a olvidarlos, construyendo, de allí en más, una visión acorde con la idea de un Paraguay mestizo. Ese nuevo «país », iniciado a partir de 1811 trae consigo la marca de la negación de la identidad indígena y afrodescendiente. *

* Manuscrit reçu en décembre 2009, accepté pour publication en janvier 2011.

\section{Notas}

Agradecemos a Capucine Boidin y a los evaluadores anónimos de este artículo por sus sugerencias y comentarios a versiones previas del texto. El orden de aparición de los nombres de los autores de este artículo es exclusivamente alfabético.

1. El diplomático paraguayo Gregorio Benítez expresa en 1889 una visión del Paraguay que perduraría por mucho tiempo: « Es preciso olvidar o alterar la Historia del Río de la Plata para negar que toda la existencia del Paraguay moderno es un litigio de 50 años con Buenos Aires. Empieza con la Junta Provisoria en 1810, continúa con el gobierno de Rosas y acaba con el de Mitre. Llámasele la China de América, él no es sino el Paraguay, pueblo cristiano, europeo de raza, que habla el idioma castellano y que un día fue parte del pueblo argentino y capital de Buenos Aires » (Biblioteca Nacional del Paraguay, Colección Juan O’Leary, Gaveta 1. Agradecemos la referencia a Liliana Brezzo. Subrayado de los autores).

2. Este legajo que se encuentra en el Museo Mitre contiene los documentos redactados por Belgrano en su campaña al Paraguay. Salvo el Reglamento que ocupa las primeras fojas, el resto de los documentos están en castellano y guaraní en dos columnas. Romero (1988) las transcribió tal y como figuran en la documentación. Se puede consultar también un trabajo previo de Morinigo (1969). El uso del guaraní por parte de Belgrano merecería un estudio pormenorizado de los especialistas en la lengua.

3. Algunos autores han definido el Reglamento de Belgrano como la primera « constitución escrita » del Río de la Plata (Caillet-Bois 1970). Sin embargo, este documento era heredero en varios puntos al decreto real de 1803 que ordenaba, entre otras cosas, la formación de un gobierno misionero autónomo. Aparentemente fue diseñado por Belgrano previa aprobación de la Junta. Esto se deduce de una carta que dirige a Saavedra el 31 de enero de 1811 en la que dice: « El Reglamento para los Pueblos de Misiones si ha sido aprobado por la Junta, como lo espero, es preciso que V. haga presente que se mande imprimir y se me remitan cuantos ejemplares sea posible, a fin de tener facilidad de hacerlos 
circular, y de que llegue a noticia de todos los naturales, y si se puede, de los Paraguayos, que desean mucho venir a poblar en estos Países, que son mucho más fértiles y de mejor disposición para los ganados que los suyos » (Belgrano 2001 [1811], p. 100, publicado como carta XXVII).

4. Un informe del obispo Paravicino en 1743 explicaba la localización de esta manera: « Cuatro curatos que son el Itá que dista doce leguas de la ciudad, Itapé treinta y cinco (y treinta y siete indios), Caazapá unas cincuenta, y Yuty más de sesenta leguas están a cargo de los religiosos de San Francisco. Y lo seis restantes que son Ypané, que dista de esta dicha ciudad seis leguas, Guarambaré, nueve, los Altos, doce, Atyrá, quince, Tobatí diecisiete o dieciocho y Yaguarón catorce » (AGI, Charcas, 374).

5. Para el pueblo de Emboscada ver los textos de Granda (1983) y Blujaki (1980).

6. Dentro de la población no indígena ha de incluirse a la población parda y a los indígenas de las encomiendas que viven en las mismas como yanaconas. El obispo no hace la diferenciación.

7. El censo de 1799 se encuentra en AGN, Sala VII, legajo 2636, pertenece al Fondo Andrés Lamas, legajo 33, y fue trabajado por Ernesto Maeder (1975). El de 1846 se encuentra en la sección Nueva Encuadernación del Archivo Nacional de Asunción, Paraguay, disperso para varios volúmenes y fue trabajado por John Hoyt Williams (1976). Seguramente este 0,5 \% en 1846 no refleje el verdadero peso de la población indígena: en muchos pueblos de indios figura sólo la población foránea y no la indígena, como por ejemplo en Yuty y en los pueblos ex jesuíticos de San Ignacio, Santa María, Santa Rosa y Santiago. Sin embargo, aunque esta población llamada foránea sea contabilizada como indígena, esta misma población no alcanzaría el $10 \%$ de la población total del Paraguay a mediados del siglo XIX.

8. Para un estudio de lo que acontecía en las ex misiones jesuíticas a partir de la época de la expulsión ver Boidin (2004). Ver también, por ejemplo, ANA, SH, 152.5 donde se informa que el corregidor y el cabildo de Santa María piden en guaraní al gobernador Joaquín de Alos la expulsión de los arrendatarios en 1788. Acerca de este documento, veáse el artículo de Melià en este mismo volumen (texto y apéndice II).

9. Estamos acostumbrados a referirnos exclusivamente a la población de los «pueblos de indios » como la población indígena del Paraguay. Sin embargo, desde que los jesuitas fueron expulsados y las tierras al norte del Manduvirá fueron reconquistadas, el universo indígena se extendía más allá de lo guaraní. Incluso una nueva forma de relacionamiento se va a instaurar con estos grupos indígenas (mbayá, guaná, chané, payaguá). Esta nueva reconquista, «invasión de estancieros-milicianos » (Susnik 1990-1991, p. 62; ver también Telesca 2009a) se caracterizaría no por la creación de pueblos de indios sino por el uso de la fuerza física (Susnik 1990-1991; Areces 2007a et b). La misma política contra estos grupos continuó durante el período de la Independencia hasta hacerlos desaparecer del territorio por medio de la expulsión o el exterminio (Susnik y Chase Sardi 1992, pp. 235-243).

10. Varios autores han llamado la atención sobre el fenómeno de la disminución demográfica indígena en el Paraguay desde diferentes puntos de vista (Maeder 1975; Garavaglia 1983, 1987). Sobre las fugas de los guaraníes de sus misiones existen varios trabajos (Susnik 1966; Wilde 2001, 2003, 2009; Telesca 2008). Mörner (1969, pp. 72-74) también presenta casos parecidos en el resto de América.

11. El porcentaje es respecto a la población parda libre total. En el censo de 1846 los que no son pardos son denominados como «blancos ». El censo mismo se divide en dos.

12. «Esto proviene de que los amos de las esclavas abrigan en sus casas a los indios prófugos; les toleran y disimula el cohabitar por el vil interés de la sucesión, pasando después a hacerlos casar porque de este modo cuenta con un esclavo disimulado » (AGN, Biblioteca Nacional, manuscrito 1688).

13. El $25 \%$ de los poseedores de mayor cantidad de tierras se quedan con el $65,3 \%$ de las tierras en Pilar y el 65,5\% en Concepción, mientras que el $50 \%$ de los que menos recibieron con el 13,7 \% de las tierras distribuidas en Pilar y el 13,4\% en Concepción (Telesca 2009a).

14. Si bien es cierto que el Paraguay era una provincia autónoma desde siglos previos, existían otras villas con sus respectivos cabildos con una identidad propia tan fuerte como la asuncena. Entre ellas se destaca Villa Rica la cual siempre tuvo altercados con la capital provincial, incluso durante las revueltas comuneras. En el Congreso General de la Provincia, ocurrido entre el 17 y 20 de junio de 1811, se tuvo que designar a un diputado para el Congreso General en Buenos Aires, el elegido fue el Dr. Francia. Sin embargo, a la hora de la votación, los representantes de las villas que poseían cabildo 
(Villa Rica, Curuguaty y Pilar) al voto general añadían que «siempre que la Excelentísima Junta de Buenos Aires juzgase necesario que la villa de su representación enviase igualmente un diputado particular de su parte al Congreso General de las Provincias estaría su República pronta a verificarlo » (Francia 2009, p. 101).

15. Las Misiones Guaraníes desde 1803 representaban una unidad administrativa que, a partir de 1805, pasará a depender del gobernador del Paraguay. Hacia 1810 la población aproximada era de 35000 personas, de las cuales unas 15000 vivían en la región de Santiago y Candelaria desde el río Tebicuary hasta ambas márgenes del río Paraná.

16. En el primer bando de la Junta del 22 de junio en su quinto ítem establece que « el Comandante D. Blas José de Rojas sea Subdelegado del departamento de Santiago, con agregación de los pueblos de Itapúa, Trinidad y Jesús, y al mismo tiempo con el cargo de Comandante de aquella frontera; y que por lo tocante a la subdelegación de Candelaria con los pueblos restantes de su antigua demarcación, nombre la Junta el Subdelegado que corresponde » (Francia 2009, p. 114).

17. El objetivo central de los congresos de los mil diputados de octubre de 1813 y 1814 era definir la forma de gobierno a adoptar (dos cónsules y una dictadura por cinco años respectivamente). Sin embargo en este último se resolvió reducir el número de los diputados a la cuarta parte, como lo fue el de 1811, y se reuniría en vez de en octubre en mayo. El congreso de 1816 nombró a José Gaspar de Francia como « Dictador perpetuo de la República durante su vida, con calidad de ser sin ejemplar » (Francia 2009, p. 424). También se resolvió que se tendrá Congreso General cada vez que el Dictador lo viese necesario, dejando de lado la obligatoriedad anual que se había resuelto en 1813. Este congreso de 1816 fue el último durante la vida del Doctor Francia. Por esta razón, no es fácil realizar una valoración de los congresos de los mil diputados. Si bien la convocatoria era amplia y llena de reconocimientos de los derechos de los ciudadanos, no es sencillo de conciliar con la resolución primero de disminuir su número y luego de auto-eliminarse quedando subordinada su convocatoria a que lo crea conveniente el Dr. Francia.

18. « Desde el año de 1785 cesó la exacción del tributo del marco de plata en virtud de un decreto del Gobernador Intendente Don Pedro de Melo con fecha 15 de marzo de 1785 »(ANA, Libro de Caja 1772-1784, Villa Rica).

\section{REFERENCIAS CITADAS}

Abreviaturas

AGI Archivo General de Indias, Sevilla, España

AGN Archivo General de la Nación, Buenos Aires, Argentina

ANA Archivo Nacional de Asunción, Paraguay

SH Sección Historia

NE Sección Nueva Encuadernación

Aguirre Juan Francisco de

1949 «Diario del Capitán de Fragata Juan Francisco Aguirre. Tomo II - Primera parte », Revista de la Biblioteca Nacional, 18, Buenos Aires [1793-1798].

ARECES Nidia

2007a Estado y frontera en el Paraguay. Concepción durante el gobierno del Dr. Francia, Universidad Católica, Asunción.

2007b «La "función" de 1796 y la matanza de Mbayás en Concepción, frontera norte paraguaya », Memoria Americana, 15, pp. 103-134. 
Belgrano Manuel

2001 Epistolario belgraniano, Taurus, Buenos Aires.

Blujaki Agustín

1980 Pueblos de pardos libres: San Agustín de Emboscada, Imprenta Militar, Asunción.

BoIDIN Capucine

2004 Guerre et métissage au Paraguay: deux compagnies rurales de San Ignacio Guasu (2001-1767), tesis doctoral, Université Paris X-Nanterre, Nanterre.

2006 «Esclaves, pardos et milices au Paraguay (XVII ${ }^{\mathrm{e}}-\mathrm{XIX}^{\mathrm{e}}$ siècles)», in Stella Sandro y Carmen Bernand (eds), D'esclave à soldat. Miliciens et soldats d'origine servile, $X I I I^{e}-X X I^{e}$ siècles, L'Harmattan, París, pp. 341-364.

Caballero Campos Herib

2006 De moneda a mercancía del rey. Efectos y funcionamiento de la Real Renta de Tabaco y naipes en la provincia del Paraguay (1779-1811), Arandura, Asunción.

\section{COONEY Jerry}

1990 Economía y sociedad en la Intendencia del Paraguay, CPES, Asunción.

2006 «Los yerbales del norte: la explotación de la frontera del Paraguay, 1776$1810 »$, in Thomas Whigham y Jerry Cooney (eds), Campo y frontera. El Paraguay al fin de la era colonial, Servilibro, Asunción, pp. 35-61.

\section{Chaves Julio César}

1959 Historia de las relaciones entre Buenos-Ayres y el Paraguay, Niza, Asunción/Buenos Aires.

1985 El Supremo Dictador. Biografía de José Gaspar de Francia, Carlos Schauman Editor, Asunción.

CAILlet-Bois Ricardo

1970 «Belgrano y la cultura », Boletín de la Academia Nacional de la Historia, 139, pp. 367-378.

Chiaramonte José Carlos

1989 «Formas de identidad en el Río de La Plata luego de 1810 », Boletín del Instituto de Historia Argentina y Americana Dr. Emilio Ravignani, 1, pp. 71-92.

2000 «Fundamentos iusnaturalistas de los movimientos de Independencia », Boletín del Instituto de Historia Argentina y Americana Dr. Emilio Ravignani, 22, pp. 33-71.

Francia José Gaspar de

2009 Francia: 1762-1817. Colección Doroteo Bareiro del Archivo Nacional de Asunción, edición comentada, aumentada y corregida, Tiempos de Historia, Asunción.

Garavaglia Juan Carlos

1983 Mercado interno y economía colonial, Grijalbo, México. 
1987 "Campesinos y soldados: dos siglos en la historia rural del Paraguay », in Juan Carlos Garavaglia, Economía, sociedad y regiones, Ediciones de la Flor, Buenos Aires, pp. 193-260.

GRANDA Germán de

1983 " Origen, función y estructura de un pueblo de negros y mulatos libres en el Paraguay del siglo xviII (San Agustín de la Emboscada) », Revista Paraguaya de Sociología, 57, pp. 7-36.

KLeINPENNING Jan M. G.

2003 Paraguay 1511-1870. A thematic geography of its development, Vervuert Verlag, Frankfurt.

MAeder Ernesto J. A.

1975 «La población en el Paraguay en 1799. El censo del gobernador Lázaro de Ribera », Estudios Paraguayos, 3 (1), pp. 63-86.

1992 Misiones del Paraguay: conflictos y disolución de la sociedad guaraní (17681850), Mapfre, Madrid.

MAEDER Ernesto J. A. y Ramón GutiérReZ

1995 Atlas histórico del Nordeste Argentino, IIGHI, Resistencia.

Morinigo Marcos Augusto

1969 «Para la historia del español en la Argentina. Las cartas guaraníes del General Belgrano », Boletín de la Academia Argentina de Letras, 34 (131132), pp. 49-72.

MöRner Magnus

1969 La mezcla de razas en la historia de América Latina, Paidós, Buenos Aires.

PoEnitz Alfredo

1987 Proceso de ocupación espacial y poblamiento al sur del Río Miriñay (17691869), Instituto de Investigaciones Geohistóricas, Resistencia.

QuiJada Mónica, Carmen Bernand y Arnd Schneider

2000 Homogeneidad y nación. Con un estudio de caso: Argentina, siglos XIX y XX, Consejo Superior de Investigaciones Científicas, Madrid.

Rivarola Milda

1994 Vagos, pobres y soldados, Centro Paraguayo de Estudios Sociológicos, Asunción.

Robertson John Paris y William Parish Robertson

1988 Cartas sobre el Paraguay. II, Hyspamérica, Buenos Aires [1938].

ROMERo Roberto A.

1988 Antecedentes de la Independencia paraguaya. Las proclamas castellanoguaraní del general Belgrano, Ediciones Intento, Asunción.

ROMERo DE Viola Blanca Rosa

1987 Paraguay siglo dieciocho, período de transición, Ediciones Comuneros, Asunción.

SUSNIK Branislava

1966 El indio colonial del Paraguay. II. Los tres pueblos guaranies de las misiones (1767-1803), Museo Etnográfico Andrés Barbero, Asunción. 
1990-1991 Una visión socio-antropológica del Paraguay del Siglo xVIII, Museo etnográfico Andrés Barbero, Asunción.

1992 Una visión socio-antropológica del Paraguay del Siglo XIX. Parte 1ra, Museo etnográfico Andrés Barbero, Asunción.

SusNik Branislava y Miguel CHASE-SARDI

1992 Los indios del Paraguay, Mapfre, Madrid.

TelesCa Ignacio

2008 «Reflexiones acerca de la identidad del Paraguay en los albores de la Independencia, de españoles a paraguayos », Historia Paraguaya, 48, pp. 295-332.

2009a Tras los expulsos. Cambios demográficos y territoriales en el Paraguay después de la expulsión de los jesuitas, CEADUC, Asunción.

2009b «Mercedes reales y concentración de tierras. El nacimiento del latifundio en Paraguay en tiempos de la Independencia », Historia Paraguaya, 49, pp. 249-290.

TReLles Manuel Ricardo

1867 Anexos a la Memoria sobre cuestión de límites entre la República Argentina y el Paraguay, Imprenta del Comercio del Plata, Buenos Aires.

VeLÁzQUEz Rafael Eladio

1965 El Paraguay de 1811, edición del autor, Asunción.

Torre Manuel Antonio

1761 «Visita a su diócesis del obispo Manuel Antonio de la Torre », Miscelánea Ayala, LIX, manuscrito II-2872, Museo Naval de Madrid, Madrid, pp. 233-325.

Whigham Thomas

1995 «Paraguay's pueblos de Indios: echoes of a missionary past », in Erik Langer y Robert H. Jackson (eds), The New Latin American Mission History, University of Nebraska Press, Lincoln, pp. 157-188.

2002 The Paraguayan war. 1. Causes and early conduct, University of Nebraska Press, Lincoln/London.

2009 Lo que el río se llevó. Estado y comercio en Paraguay y Corrientes, 1776-1870, CEADUC, Asunción.

WILDE Guillermo

1999 « ¿Segregación o asimilación? La política indiana en América meridional a fines del período colonial », Revista de Indias, 59 (217), pp. 619-644.

2001 «Los guaraníes después de la expulsión de los jesuitas. Dinámicas políticas y prácticas simbólicas », Revista Complutense de Historia de América, 27, pp. 69-109.

2003 "Guaraníes, "gauchos" e "indios infieles" en el proceso de disgregación de las antiguas doctrinas jesuíticas del Paraguay », Suplemento Antropológico, 38 (2), pp. 73-130.

2009 Religión y poder en las misiones guaranies, Editorial SB, Buenos Aires.

WiLliams John Hoyt

1976 « Observations on the Paraguayan Census of 1846 », Hispanic American Historical Review, 56 (3), pp. 424-437. 